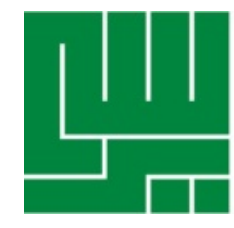

\title{
Pengaruh Kepribadian Tangguh terhadap Perilaku Kerja Inovatif pada Karyawan PT X
}

\section{The Impact of Hardiness Personality on Innovative Work Behavior among PT X Employees}

\author{
Erita Marisdianti, Arum Etikariena
}

Fakultas Psikologi Universitas Indonesia

Email:arum.etikariena@ui.ac.id /arum.hidayat@gmail.com

\author{
KATA KUNCI Perilaku Kerja Inovatif, Kepribadian Tangguh, Regresi, \\ Perusahaan Manufaktur Kapal. \\ KEYWORDS Innovative Work Behavior, Hardiness Personality, Regression, \\ Ship Manufacturing Company.
}

ABSTRAK Penelitian ini dilakukan untuk melihat pengaruh kepribadian tangguh terhadap perilaku kerja inovatif pada karyawan perusahaan BUMN yang bergerak pada bidang manufaktur kapal. Sebagai BUMN, perusahaan X memiliki peranan penting untuk mendukung program kerja pemerintah, inovasi diperlukan agar dapat memproduksi barang secara efisien dengan kualitas terbaik. Terdapat 121 responden dalam penelitian ini. Penelitian ini merupakan penelitian kuantitatif dengan menggunakan Skala Perilaku Kerja inovatif (2000) dan Dispositional Resilience Scale-15 (2007). Teknik analisis data yang digunakan pada penelitian ini adalah korelasi pearson product moment dan simple regression. Berdasarkan hasil penelitian diketahui bahwa kepribadian tangguh secara signifikan berhubungan dengan perilaku kerja inovatif $(r=0,40 ; p<0,01)$. Dengan hasil ini, analisis lanjutan menunjukkan bahwa kepribadian tangguh memiliki pengaruh sebesar $16,6 \%$ pada munculnya perilaku kerja inovatif $\left(\mathrm{R}^{2}=0,16, \mathrm{~F}(1,120)=26,44, \mathrm{p}<0,01\right)$. Hasil tersebut memiliki arti bahwa $16,6 \%$ perilaku kerja inovatif dipengaruhi oleh kepribadian tangguh, dan $83,4 \%$ sisanya dipengaruhi oleh faktor lain.

ABSTRACT This study was conducted to investigate the influence of hardiness personality towards innovative work behavior on employee of shipping manufacture BUMN. There were 121 respondents in this study. As a $B U M N$, company $X$ has an important role to support the government work program, innovation is needed in order to produce goods efficiently with the best quality. This research is a quantitative research that using Innovative Work Behavior Scale (2000) and Dispositional Resilience Scale-15 (2007). The analysis technique used in this study is simple regression. The result shows that there was a positive and significant 
correlation of hardiness personality to innovative work behavior on employee of shipping manufacture BUMN $(r=0.40 ; p<0.01)$. It also shows that hardiness personality has $16.6 \%$ impact on innovative work behavior $\left(R^{2}=0.16, F(1,120)=26.44, p<0.01\right)$. Based on the results of the research, it shows that hardiness personality could significantly affect innovative work behavior. It means that $16.6 \%$ of innovative work behavior affected by hardiness personality and the remaining $83.4 \%$ was affected by other factors.

\section{PENDAHULUAN}

Perusahaan membutuhkan pasar sebagai konsumen atas jasa atau produknya agar roda bisnisnya tetap berjalan. Kehadiran perusahaan lain dapat menjadi pesaing usaha yang mampu merebut perhatian pasar. Saat pasar lebih banyak yang tertarik pada barang atau jasa perusahaan pesaing, tentu hal ini akan dapat menjadi sebuah tantangan tersendiri. Guna merebut dan mempertahankan konsumen, perusahaan harus melakukan suatu hal yang dapat menarik bagi konsumen. Salah satunya dengan melakukan inovasi-inovasi terkait jasa atau produknya. Inovasi diakui sebagai suatu perilaku yang bermanfaat dan sebagai sebuah pondasi dari organisasi yang berperforma baik (Vinarski-Peretz \& Carmeli, 2011). Langkah-langkah perusahaan dalam berinovasi menjadi tanggung jawab bersama, tak terkecuali para karyawan. Hana (2013) mengatakan bahwa kesuksesan sebuah organisasi ditentukan oleh pengetahuan, pengalaman, aktivitas kreatif, kualitas, pembelajaran, penelitian, dan pengembangan dari para karyawannya. Pernyataan ini memberikan gambaran mengenai pentingnya peran karyawan bagi kesuksesan perusahaan.

Inovasi memiliki bahan dasar berupa ide dan karyawan yang mencetuskan, mengembangkan, mengolah, dan memodifikasi ide (West \& Farr, 1990; Scott \& Bruce, 1994). Dalam Etikariena dan Muluk (2014) disebutkan bahwa individu merupakan pencetus dan pelaksana ide inovatif. Oleh karena itu penggalian mengenai inovasi pada level individu yang disebut dengan perilaku kerja inovatif menjadi penting, mengingat level individu berperan sebagai titik pertama inovasi berasal.

Beberapa penelitian telah membahas mengenai prediktor perilaku kerja inovatif pada level individu. Hammond, Neff, Mac, Farr, Schwall, dan Zhao (2011) menemukan beberapa hal yang melatarbelakangi seseorang melakukan perilaku kerja inovatif adalah perbedaan individu, karakteristik pekerjaan, dan faktor lingkungan. Berdasarkan hasil penelitian terdahulu ditemukan openness to experience dan kepribadian kreatif berkorelasi positif dengan perilaku kerja inovatif (Hammond, $\mathrm{dkk}, 2011)$. Motivasi juga ditemukan memiliki hubungan yang kuat dengan inovasi individu (Hammond dkk, 2011). Suasana hati seseorang ditemukan juga berpengaruh terhadap perilaku kerja inovatif (Amabile, Barsade, Mueller, \& Staw, 2005).

Faktor eksternal, atau faktor yang berasal dari luar diri individu dapat dikaji berdasarkan konteks, pekerjaan, kelompok, dan organisasi. Karakteristik pekerjaan yang banyak dikaji dan terbukti berhubungan dengan perilaku kerja inovatif adalah kompleksitas pekerjaan, otonomi, dan ekspektasi terhadap peran (Hammond, $\mathrm{dkk}, 2011$ ). Selanjutnya, prediktor perilaku kerja inovatif dianalisis dari segi lingkungan dapat ditinjau melalui dukungan terhadap inovasi, iklim organisasi, ketersediaan sumber, hubungan atasan dan bawahan, serta kepemimpinan transformasional yang kesemuanya ditemukan berhubungan secara positif terhadap perilaku kerja inovasi individu (Hammond dkk, 2011).

Penelitian-penelitian yang disebutkan di atas, memberikan gambaran 
bahwa perilaku kerja inovatif turut dipengaruhi oleh lingkungan dan situasisituasi yang dihadapi karyawan. Dalam bekerja tentu memiliki tujuan yang ingin dicapai. Adanya kesenjangan antara tujuan dan keadaan saat ini merupakan suatu masalah yang harus ditangai oleh karyawan. Masalah ini akan semakin buruk apabila karyawan tidak memiliki sumber yang dapat memfasilitasi kebutuhan karyawan dalam menjawab tuntutan perusahaan. Perusahaan yang menuntut karyawannya untuk menyelesaikan permasalahan yang dihadapi dengan meminta karyawannya untuk mengerjakan hal-hal yang berat dalam waktu yang singkat atau dengan kata lain karyawan memiliki beban kerja yang berat (Fox, Dawyer, \& Ganster, 1993). Beban kerja yang berat tersebut dapat dimaknai sebagai tekanan psikologis bagi para karyawan (Fox dkk, 1993). Selain tuntutan kerja, rekan kerja dan atasan yang tidak kooperatif juga dapat menjadi sumber tekanan bagi karyawan. Inovasi yang diciptakan oleh karyawan dapat mengubah rangka kerja yang sudah ada sebelumnya dan rekan kerja cenderung untuk menolak ide inovatif karyawan (Janssen, 2003). Penolakan terhadap inovasi dilakukan oleh rekan kerja untuk menghindari rasa tidak nyaman dan tekanan saat terjadi perubahan dan hal ini dapat menyebabkan rasa frustasi, pertentangan, dan rasa benci sehingga hubungan karyawan inovatif dengan rekan kerjanya menjadi buruk (Janssen, 2004). Tuntutan kerja yang berat dan kompleks, serta penolakan dari rekan kerja membuat inovasi yang ditampilkan karyawan menjadi sebuah hal yang menekan (Janssen, 2004), yang dapat dikatakan bahwa karyawan mengalami stres kerja saat inovasi yang ditampilkannya terhambat oleh lingkungan sekitar.

Sebuah penelitian oleh Yosephine (2013) menemukan bahwa stres kerja memiliki hubungan yang signifikan dengan perilaku kerja inovatif dengan arah negatif, yang berarti semakin tinggi tingkat stres kerja yang dialami oleh karyawan maka semakin rendah perilaku kerja inovatif karyawan. Oleh karena itu, peneliti tergerak untuk melakukan penelitian mengenai kepribadian yang dapat mengatasi stres kerja yang dialami karyawan. Roberts, Kuncel, Shiner, Caspi dan Goldberg (2007) mengatakan bahwa salah satu penyebab penting dari perilaku adalah kepribadian. Hal ini didukung oleh $\mathrm{Li}$, Barrick, Zimmerman, dan Chiaburu (2014) yang mengatakan bahwa kepribadian merupakan konsep utama, pengetahuan tentang kepribadian dapat membantu untuk memahami alasan dan cara seseorang berperilaku.

Terkait dengan peran kepribadian, pada penelitian ini kepribadian yang akan dikaji adalah hardiness, yang selanjutnya diterjemahkan menjadi kepribadian tangguh. Kepribadian tangguh berbicara mengenai kecenderungan seseorang dalam berespon, berpikir, dan merasa pada situasi yang menekan (Kobasa, 1982). Tipe kepribadian tangguh ini dipilih karena situasi yang dibahas di dalam kepribadian tangguh memiliki keterkaitan dengan situasi ketika inovasi dalam perusahaan perlu dilakukan yaitu pada situasi-situasi yang menekan, misalnya saat perusahaan sedang dalam kondisi yang kurang baik, adanya tuntutan dari perusahaan, ataupun konflik dengan rekan kerja. Individu yang memiliki tingkat kepribadian tangguh yang tinggi menunjukkan tiga karakteristik yaitu, merasa bahwa tantangan yang hadir dapat meningkatkan kapasitas dirinya, memiliki komitmen yang kuat untuk menyelesaikan pekerjaan atau permasalahan yang sedang dihadapi, dan merasa bahwa yang dilakukannya dapat membuat sesuatu menjadi lebih baik (Maddi, 2013).

Karakteristik kepribadian tangguh memandang tantangan atau permasalahan sebagai hal yang bermanfaat untuk perkembangan diri, berkomitmen untuk menyelesaikan pekerjaan hingga masalah terpecahkan, dan meyakini bahwa yang dilakukannya dapat mengubah keadaan menjadi lebih baik (Maddi, 2013), memberikan individu keberanian dan motivasi untuk menemukan cara yang 
konstruktif dan cara yang dapat diterima oleh orang lain untuk menurunkan tingkat tekanan yang ada di sekitar individu (Maddi, 2013). Hal ini juga diperlukan dalam menampilkan perilaku kerja inovatif. Terdapat beberapa penelitian yang melihat keterkaitan antara kepribadian tangguh dan perilaku kerja inovatif. Pada penelitian yang dilakukan oleh Maddi (2006) pada para karyawan Illinois Bell Telephone (IBT), menunjukkan bahwa karyawan yang memiliki tingkat kepribadian tangguh yang tinggi menampilkan daya tahan yang baik sehingga individu dapat menampilkan emosi positif baik bagi diri sendiri maupun saat berinteraksi dengan orang lain yang dapat memfasilitasi individu dalam menampilkan perilaku kerja inovatif.

Penelitian oleh Roberg (2007) pada 255 karyawan pada berbagai macam bidang pekerjaan. Penelitian ini melihat korelasi skor kepribadian tangguh secara keseluruhan dengan skor perilaku kerja inovasi secara keseluruhan dan melihat hubungan dari masing-masing dimensi dan seluruh tahapan dari perilaku kerja inovatif. Hasil menunjukkan bahwa skor total kepribadian tangguh memiliki korelasi positif secara signifikan dengan skor total inovasi individu.

Selanjutnya, penelitian Bartone, Rolan, Picano, dan Williams (2008) pada kandidat pasukan khusus militer Amerika Serikat menemukan bahwa kepribadian tangguh merupakan karakteristik yang diperlukan saat menghadapi tekanan untuk mencapai kesuksesan terutama pada pekerjaan yang memiliki tuntutan kerja yang berat. Pasukan khusus militer ini berbeda dengan pasukan militer pada umumnya. Pasukan khusus militer Amerika Serikat ini, diharapkan dapat berfungsi secara efektif pada kelompok kecil dan mampu beradaptasi secara cepat pada lingkungan yang berubah-ubah, misi yang ditugaskan, dan konteks budaya yang berbeda-beda (Bartone dkk, 1998; Bartone $\mathrm{dkk}, 2008)$. Pasukan ini juga merupakan pasukan yang independen, relatif kurang mendapatkan bantuan, dan berada pada kondisi yang tidak pasti yang membutuhkan solusi secara spontan untuk mengatasi tantangan. Solusi yang dihasilkan oleh pasukan militer sebenarnya tidak bisa disamakan dengan inovasi namun karena solusi merupakan hasil yang baru dari cara pasukan militer menghadapi masalah, maka peneliti memaknai solusi tersebut merupakan suatu bentuk inovasi yang dihasilkan oleh pasukan militer khusus. Hasil dari penelitian yang dilakukan oleh Bartone dkk (2008) menemukan bahwa kepribadian tangguh memiliki pengaruh yang signifikan walaupun kecil terhadap kesuksesan para kandidat di sekolah pasukan militer khusus Amerika Serikat.

Berdasarkan penelitian tersebut, menunjukkan bahwa perilaku kerja inovatif yang dilakukan oleh karyawan memiliki peranan penting bagi perusahaan dan kepribadian tangguh membahas cara individu berpikir, merespon, dan merasa pada situasi menekan yang merupakan situasi saat perilaku kerja inovatif dibutuhkan dan ditampilkan. Oleh karena itu, pada penelitian ini akan dikaji apakah terdapat pengaruh kepribadian tangguh terhadap perilaku kerja inovatif. Penelitian ini akan dilakukan pada perusahaan BUMN yang bergerak pada bidang manufaktur.

Pemilihan responden penelitian yaitu karyawan perusahaan $\mathrm{X}$, yaitu perusahaan BUMN bidang manufaktur bidang perkapalan memiliki urgensi tersendiri. Salah satu konsultan bisnis bernama Bizfilling mengatakan dalam situsnya bahwa kunci dari keberhasilan produksi pada perusahaan manufaktur adalah perencanaan yang matang $(\mathrm{NN}$, NY). Berdasarkan hal tersebut, perusahaan manufaktur harus melaksanakan poses produksinya sesuai standar yang baku. Di samping itu, perusahaan $\mathrm{X}$ yang berstatus BUMN, memegang peranan penting untuk mendukung program kerja pemerintah yang ditujukan untuk meningkatkan kesejahteraan warga negara. Salah satu program kerja yang memiliki keterkaitan dengan perusahaan $\mathrm{X}$ adalah tol laut yang juga merupakan program kerja unggulan 
pemerintahan. Program kerja ini tertuang dalam butir pertama Nawacita yaitu keinginan untuk memperkuat jati diri Indonesia sebagai negara maritim. Tuntutan kerja pada pemerintahan Joko Widodo dan Jusuf Kalla yang dikenal dengan gerak cepat, menjadi tantangan tersendiri bagi perusahaan-perusahaan BUMN. Sebelum program kerja tol laut dilaksanakan, perusahaan $\mathrm{X}$ berproduksi secara rutin. Meski demikian, semenjak program kerja tol laut dijalankan, perusahaan $\mathrm{X}$ dituntut untuk memproduksi kapal secara lebih intens. Dalam proyek ini, pemerintah memberikan rentang waktu selama lima tahun bagi PT $\mathrm{X}$ untuk dapat mengakomodir kebutuhan tol laut. Mengingat Indonesia memiliki wilayah laut yang luas dan waktu yang diberikan kepada PT $X$ terbatas, maka hal ini dapat menimbulkan tekanan tersendiri bagi PT X. Tuntutan untuk memproduksi kapal secara lebih intens dibandingkan sebelumnya merupakan keunikan tersendiri dalam penelitian ini, sehingga peneliti memutuskan untuk melakukan penelitian untuk melihat pengaruh kepribadian tangguh terhadap perilaku kerja inovatif pada 150 karyawan PT X.

\section{Perilaku Kerja Inovatif}

Kanter (1988) mengemukakan bahwa inovasi merupakan proses yang di dalamnya terdiri dari beberapa tahap yaitu idea generation (penciptaan ide), coalition building (mencari dukungan), idea realization (realisasi ide), dan transfer or difussion (menyebarluaskan model). Terdapat pula tokoh lain yang menjelaskan mengenai perilaku kerja inovatif yaitu West dan Farr (1990) yang mengatakan bahwa perilaku kerja inovatif merupakan penciptaan ide, mempromosikan ide, dan mengaplikasikan ide yang dilakukan secara sengaja pada individu yang bekerja, kelompok, atau organisasi dengan tujuan untuk memperoleh manfaat dari performa kerja, kelompok, dan organisasi.

Berdasarkan pendapat dari Kanter (1988) juga West dan Farr (1990) tersebut, maka Scott dan Bruce (1994) mengatakan bahwa perilaku kerja inovatif merupakan proses individu dalam menciptakan ide sebagai solusi atas permasalahan, pembentukan koalisi sebagai usaha untuk mendukung ide, dan mengimplementasikan ide ke dalam bentuk model yang ditampilkan atas kebutuhan akan inovasi di lingkungannya. Pernyataan Scott dan Bruce (1994) menjadi dasar bagi Janssen (2000) dalam menjelaskan perilaku kerja inovatif. Janssen (2000) mendefinisikan perilaku kerja inovatif sebagai upaya terencana yang dilakukan individu dalam menciptakan ide, mempromosikan, dan mengimplementasikannya pada organisasi tempatnya bekerja yang ditujukan untuk memperoleh manfaat bagi performa individu, kelompok, dan organisasi. Menciptakan ide merupakan suatu tahapan yang berisi tentang memikirkan dan membuat pendekatan atau ide-ide baru serta solusi terkait isu-isu pekerjaan. Menciptakan ide didahului dengan kesadaran individu tentang adanya permasalahan yang membutuhkan penanganan segera atau pencarian kesempatan-kesempatan untuk meningkatkan kondisi yang sudah ada (Janssen, 2000).

Setelah seseorang menciptakan idenya, individu tersebut mempromosikan idenya. Tahapan ini berguna untuk mendapatkan dukungan dalam mengimplementasikan ide ke dalam produk, jasa, metode, atau teknik. Dalam tahapan mempromosikan ide, individu mencari dukungan dengan membuat kelompok kerja yang dapat memberikan individu bantuan saat mengimplementasikan idenya (Janssen, 2000). Setelah orang tersebut mendapatkan dukungan, dilanjutkan tahapan implementasi ide. Pada tahap ini, ide diimplementasikan dalam bentuk model atau prototype yang dapat diaplikasikan dan diujikan pada individu dengan pekerjaan tertentu, kelompok dan organisasi. Tahap implementasi ide di dalamnya terdiri dari aktivitas mengembangkan produk, jasa, dan 
proses kerja baru serta menguji dan memodifikasi kembali hasil implementasi ide tersebut (Kanter,dalam De Jong \& Den Hartog, 2010).

\section{Kepribadian Tangguh (Hardiness Personality)}

$\begin{array}{llr}\text { Kepribadian } & \text { tangguh } & \text { merupakan } \\ \text { kecenderungan } & \text { seseorang } & \text { untuk }\end{array}$ menampilkan resilience (daya tahan) yang baik dengan memandang permasalahan sebagai tantangan untuk berkembang, berkomitmen untuk menyelesaikan permasalahan, dan meyakini bahwa dirinya memiliki kontrol untuk menyelesaikan permasalahan (Bartone, Ursano, Wright, \& Ingraham, 1989). Sesukar apapun kondisi yang dihadapi, seseorang yang memiliki komitmen tidak akan meninggalkan sesuatu yang dikerjakannya (Maddi, 2013). Seseorang yang memiliki komitmen mengetahui alasan di balik keikutsertaannya pada suatu hal. Oleh karenanya, saat mengerjakan seseuatu orang tersebut memahami tujuan yang ingin dicapainya. Kepemilikian tujuan (sense of purpose) membantu seseorang untuk meminimalkan dampak dari adanya peristiwa yang menekan (Kobasa, 1982). Individu yang berkomitmen terhadap pekerjaannya akan memandang bahwa dirinya sedang mengerjakan sesuatu yang penting dan berarti (Bartone dkk, 1989).

Karakteristik yang kedua yaitu kontrol. Kontrol berbicara mengenai kecenderungan seseorang untuk percaya dan berperilaku yang menggambarkan bahwa dirinya dapat memengaruhi suatu keadaan. Seseorang yang memiliki karakteristik kontrol, tidak hanya pasrah menerima keadaan namun turut melibatkan diri dalam menyelesaikan suatu permasalahan (Kobasa, 1982). Kontrol memfasilitasi seseorang untuk mempersepsikan bahwa suatu kejadian merupakan hasil dari sesuatu yang dikerjakannya, oleh karenanya seseorang dapat menempatkan suatu hal sebagai subjek yang dapat diarahkan atau dimanipulasi olehnya (Kobasa, 1982).
Hambatan atau peristiwa yang menekan akan dimanfaatkan sebagai suatu kejadian yang dapat menjadi pengalaman berharga bagi seseorang (Maddi, 2013).

Terakhir adalah karakteristik tantangan yang memaknai perubahan sebagai hal yang wajar terjadi dalam kehidupan, termasuk perubahan yang menekan (Maddi, 2013; Kobasa, 1982). Peristiwa yang menekan justru dimaknai sebagai sarana untuk mengembangkan kapabilitas yang dimiliki (Maddi, 2013). Seseorang merasa bahwa dengan adanya tantangan, dirinya akan dapat terus berkembang, dan hal ini tidak akan mungkin didapatkan apabila dirinya selalu berada dalam situasi yang mudah, aman, dan nyaman (Maddi, 2013). Oleh karenanya, seseorang yang memiliki karakteristik tantangan, merupakan katalis bagi lingkungan sekitarnya karena dirinya mampu mengatasi permasalahan atau ancaman yang datang (Kobasa, 1982). Ketiga karakteristik ini saling berkaitan satu sama lain. Jika seseorang hanya memiliki karakteristik tantangan maka orang tersebut akan sangat suka terhadap suatu tantangan namun belum tentu merasa terikat dengan pekerjaannya (komitmen) dan percaya bahwa dirinya mampu menaklukan tantangan (kontrol). Saat seseorang hanya memiliki karakteristik komitmen maka seseorang akan terikat dengan pekerjaannya terhadap pekerjaannya namun, belum tentu dirinya memang benar-benar menyukai tantangan atau percaya bahwa dirinya mampu menaklukan tantangan (kontrol). Terakhir, saat seseorang hanya memiliki karakteristik kontrol saja maka dirinya akan dengan sangat yakin bahwa mampu mengatasi tantangan yang dihadapi namun, belum tentu orang tersebut terikat dengan pekerjaannya (komitmen) dan benar-benar menyukai tantangan. Ketiga karakteristik ini saling berkaitan satu sama lain. Oleh karenanya, seseorang yang dikatakan memiliki kepribadian tangguh harus memiliki ketiga karakteristik tersebut (Maddi, 2006). 


\section{METODE PENELITIAN \\ Pendekatan Penelitian}

Penelitian ini

pendekatan kuantitatif

korelasional.

\section{Partisipan}

Populasi dalam penelitian ini adalah karyawan pada PT X. PT X merupakan perusahaan BUMN yang bergerak di bidang manufaktur kapal. Sampel dalam penelitian ini sebanyak 135 responden dengan karakteristik minimal kerja selama satu tahun dan minimal level pendidikan adalah SMA sederajat karena pada level Sekolah Menengah Atas, pelajaran yang diberikan lebih spesifik atau terdapat penjurusan. Responden penelitian ini berasal dari empat divisi yaitu, divisi desain, divisi rekayasa umum, divisi kapal perang, dan divisi kapal niaga. Teknik sampling yang digunakan dalam penelitian ini adalah purposive sampling dikarenakan penelitian ini menyasar populasi khusus yaitu karyawan dan karyawati pada perusahaan yang sedang melakukan inovasi atau menjadikan inovasi sebagai salah satu visi-misinya, sehingga peneliti akan langsung membidik karyawan-karyawati di perusahaan $\mathrm{X}$ sesuai kebutuhan penelitian.

\section{Instrumen Penelitian}

Penelitian ini menggunakan selfreport yaitu, responden memberikan informasi mengenai dirinya sendiri. Dalam penelitian ini, responden mengisi booklet yang terdiri dari skala perilaku kerja inovatif dan kepribadian tangguh.Pengukuran terhadap perilaku kerja inovatif menggunakan skala perilaku kerja inovatif oleh Janssen (2000) yang telah diadaptasi oleh Etikariena dan Muluk (2014) ke dalam Bahasa Indonesia, dengan nilai cronbach $\alpha=0,80$. Skala perilaku kerja inovatif ini terdiri dari sembilan butir pernyataan dengan, tiga butir pada masingmasing dimensinya. Pengukuran terhadap kepribadian tangguh menggunakan Dispositional Resillience Scale-15 (DRS15) oleh Bartone dkk (2007) yang diadaptasi oleh Novena (2013), dengan nilai cronbach $\alpha=0,83$. Masing-masing dimensi memiliki lima butir pernyataan, sehingga total butir pernyataan dalam DRS15 adalah sebanyak 15 butir.

\section{Teknik Analisis Data}

Terdapat lima teknik analisis data yang digunakan dalam penelitian ini yaitu analisis deskriptif, analisis korelasi, analisisi regresi, uji independent sample $T$ test, dan uji one-way anova.

\section{ANALISIS DAN HASIL}

Hasil penelitian menunjukkan bahwa mayoritas responden menampilkan perilaku kerja inovatif dan memiliki kepribadian tangguh yang berada pada level sedang. 
Tabel 1

Gambaran Umum Perilaku Kerja Inovatif Responden

\begin{tabular}{cccc}
\hline Klasifikasi & Mean Skala & Frekuensi & Presentase \\
\hline Rendah & $<18,10$ & 18 & 13.3 \\
Sedang & $18,10 \leq \mathrm{X} \leq 44,92$ & 82 & 60.7 \\
Tinggi & $>44,92$ & 35 & 26.9 \\
& Total & 135 & 100 \\
\hline
\end{tabular}

Tabel 2

Gambaran Umum Kepribadian Tangguh Responden

\begin{tabular}{cccc}
\hline Klasifikasi & Mean Skala & Frekuensi & Presentase \\
\hline Rendah & $<30,41$ & 0 & 0 \\
Sedang & $30,41 \leq \mathrm{X} \leq 74,58$ & 88 & 65,2 \\
Tinggi & $>74,58$ & 47 & 34,8 \\
& Total & 135 & 100 \\
\hline
\end{tabular}

Selanjutnya hasil perhitungan korelasi menunjukkan bahwa terdapat hubungan positif dan signifikan kepribadian tangguh dengan perilaku kerja inovatif $(\mathrm{r}=$ $0,40 ; \mathrm{p}<0,01)$. Pengaruh kepribadian tangguh terhadap perilaku kerja inovatif menunjukkan hasil $\left(\mathrm{R}^{2}=0,16\right.$, $\mathrm{F}(1,133)=26,44, \mathrm{p}<0.01)$. Nilai $\mathrm{R}^{2}$ sebesar 0,166 , yang berarti bahwa $16,6 \%$ perilaku kerja inovatif dipengaruhi oleh kepribadian dipengaruhi oleh faktor lain selain kepribadian tangguh. Nilai $F$ adalah 26,44 yang signifikan pada $\mathrm{p}<0,01$. Nilai signifikasi sebesar $0 \%$, kurang dari $1 \%$ yang menunjukkan bahwa hipotesis alternatif diterima, atau dengan kata lain kepribadian tangguh mempengaruhi perilaku kerja inovatif secara signifikan pada karyawan perusahaan X.

Tabel 3

Gambaran Perilaku Kerja Inovatif berdasarkan Data Demografi

\begin{tabular}{ccccc}
\hline Karakteristik & Data Partisipan & $\mathrm{N}$ & $M$ & Signifikansi \\
\hline Jenis & Laki-laki & 98 & 35,78 & $\mathrm{~F}=0,36$ \\
& Perempuan & 23 & 27,57 & $\mathrm{p}=0,00$ \\
& & & $\mathrm{p}<0,05$ \\
Usia & $15-24$ & 8 & 30,50 & $\mathrm{~F}=0,61$ \\
& $25-44$ & 72 & 33,90 & \\
& $45-64$ & 41 & 35,49 & $\mathrm{p}=0,54$ \\
Masa Kerja & & & & $\mathrm{p}>0,05$ \\
& $2-10$ & 47 & 25,50 & $\mathrm{~F}=3,553$ \\
& $>10$ & 72 & 36,02 & \\
Tingkat & & & & $\mathrm{p}=0,03$ \\
Pendidikan & SMA-SMK & 48 & 36,52 & $\mathrm{p}<0,05$ \\
& & & $\mathrm{~F}=1,67$ \\
& Diploma & 19 & 31,63 & $\mathrm{p}=0,17$ \\
& S1 & 52 & 32,60 & $\mathrm{p}>0,05$ \\
& S2 & 2 & 45,00 & \\
\hline
\end{tabular}


Di samping itu, juga ditemukan bahwa terdapat perbedaan rata-rata skor perilaku kerja inovatif yang signifikan pada aspek jenis kelamin dan masa kerja yang menunjukkan bahwa laki-laki menampilkan perilaku kerja inovatif yang lebih tinggi daripada perempuan dan karyawan dengan masa kerja di atas sepuluh tahun menampilkan perilaku kerja inovatif yang paling tinggi dibandingkan dengan karyawan dengan masa kerja di bawah dua tahun atau dua sampai sepuluh tahun. Tidak ditemukan perbedaan rata-rata skor perilaku kerja inovatif yang signifikan pada aspek usia dan tingkat pendidikan.

\section{DISKUSI}

Berdasarkan hasil penelitian ini, terbukti bahwa kepribadian tangguh berpengaruh secara signifikan terhadap perilaku kerja inovatif. Hal ini dapat terjadi karena kepribadian tangguh membantu karyawan untuk menyesuaikan dirinya terhadap situasi yang menekan. Di saat orang lain memandang situasi yang menekan sebagai suatu ancaman, karyawan yang memiliki kepribadian tangguh akan justru memandang tekanan sebagai sarana untuk mengembangkan diri (Bartone, 1989).

Dalam penelitian ini, yang menjadi responden penelitian adalah karyawan perusahaan BUMN bidang manufaktur kapal yang mendapatkan tugas dari pemerintah untuk memenuhi kebutuhan kapal yang akan digunakan dalam mendukung program kerja pemerintah yaitu tol laut. Pengerjaan proyek ini juga akan berlangsung selama lima tahun, yang dimulai sejak tahun 2015. Adanya batas waktu yang diberikan oleh pemerintah menjadi tantangan tersendiri bagi PT X. Di samping itu, adanya perbedaan beban kerja antara sebelum dan sesudah program kerja tol laut dilaksanakan dapat menjadi tekanan tersendiri bagi karyawan. Sejak program kerja tol laut dilaksanakan, karyawan perusahaan PT $X$ dituntut untuk dapat menghasilkan kapal secara lebih intens. PT $\mathrm{X}$ diminta untuk menghasilkan kapal dalam jumlah banyak dan waktu singkat untuk memenuhi kebutuhan negara.

Tuntutan kerja yang meningkat dapat memengaruhi kinerja karyawan PT X dalam menyukseskan proyek pemerintah tersebut. PT X yang merupakan perusahaan manfaktur tentu memiliki prosedur kerja yang terstandar. Adanya standar kerja dalam perusahaan dapat mengurangi inovasi-inovasi yang muncul dari para karyawannya. Di sisi lain, PT X membutuhkan adanya perilaku kerja inovatif yang ditampilkan oleh para karyawannya, mengingat inovasi merupakan hal yang penting bagi keberlangsungan perusahaan. Sebagai perusahaan BUMN yang berpengaruh besar terhadap kondisi negara dan PT $\mathrm{X}$ yang dipercaya oleh pemerintah untuk membantu program kerja permerintahan. Adanya batas waktu, beban kerja yang meningkat, dan harapan dari pihak luar agar PT X berhasil membantu program kerja tol laut pemerintah tersebut menjadi tekanan tersendiri bagi karyawan.

Hasil penelitian ini menemukan bahwa mayoritas karyawan memiliki kepribadian tangguh yang sedang, dan kepribadian tangguh yang terbukti secara signifikan memengaruhi perilaku kerja inovatif, maka hasil penelitian menunjukkan bahwa mayoritas karyawan perusahaan PT X menampilkan perilaku kerja inovatif yang sedang pula. Kepribadian tangguh yang memfasilitasi karyawan dalam menyesuaikan diri dengan tekanan yang dihadapi. Adanya waktu yang terbatas, kebiasaan karyawan yang santai dalam bekerja, dan iklim kerja yang selama ini kurang memfasilitasi karyawan untuk berinovasi yang merupakan masalah bagi kinerja perusahaan, dipandang oleh karyawan yang berkepribadian tangguh sebagai suatu hal yang wajar dalam dunia kerja sehingga karyawan tidak menghindari permasalahan tersebut, justru tergerak untuk dapat mengatasi masalah tersebut. Karyawan yang berkepribadian tangguh juga mengetahui tujuan yang ingin dicapai sehingga karyawan tersebut terus berusaha 
hingga tujuannya dapat tercapai dan meyakini bahwa dirinya akan berhasil dalam melaksanakan pekerjaannya. Oleh karena itu, kepribadian tangguh dapat membantu karyawan untuk menyesuaikan diri terhadap tekanan dan dapat membantu karyawan untuk menampilkan perilaku kerja inovatif yang berguna bagi keberlangsungan perusahaan.

Di samping beban kerja perusahaan yang berbeda antara sebelum dan sesudah program kerja tol laut dilaksanakan, terdapat sumber tekanan lain berupa penolakan dari rekan kerja. Dalam proses karyawan melakukan inovasi, rentan bagi para karyawan untuk mendapatkan penolakan dari para rekan kerjanya. Hal ini dapat membuat hubungan antara karyawan inovatif dan rekan kerjanya menjadi kurang baik, dan karyawan inovatif merasa frustasi (Janssen, 2003). Keadaan seperti ini memberikan tekanan tersendiri bagi karyawan inovatif. Meski demikian, dengan kepribadian tangguh, tekanan tersebut akan dimaknai sebagai hal yang wajar terjadi, karyawan tetap berusaha hingga tujuannya dapat tercapai dan karyawan meyakini bahwa dirinya mampu mengubah keadaan menjadi lebih baik. Oleh karena itu, hambatan-hambatan yang dihadapi karyawan tidak akan terlalu dimaknai sebagai situasi yang mengancam sehingga karyawan yang berkepribadian tangguh akan tetap menampilkan perilaku kerja inovatif.

Hasil penelitian yang menunjukkan bahwa kepribadian tangguh berpengaruh secara signifikan terhadap perilaku kerja inovatif yang berarti bahwa dengan memiliki kepribadian tangguh, karyawan akan menampilkan perilaku kerja inovatif. Temuan ini selaras dengan penelitian yang dilakukan oleh Maddi (2006) menemukan bahwa kepribadian tangguh dapat memfasilitasi karyawan dalam berinovasi dan Bartone dkk (2008) yang menemukan bahwa kepribadian tangguh memiliki korelasi positif dengan inovasi.

Pada penelitian yang dilakukan oleh Maddi (2006; 2013) yang bersifat longitudinal pada karyawan perusahaan Illinois Bell Telephone (IBT) yang pada saat itu perusahaannya sedang mengalami permasalahan yaitu tuntutan pasar yang meminta agar komunikasi dapat murah dan reliabel namun, karena keadaaan politik maka, perusahaan mengalami kesulitan untuk memenuhi pemintaan pasar. Keadaan ini menyebabkan perusahaan IBT kehilangan sepertiga karyawannya karena karyawan mengalami stres, bahkan ada yang dilaporkan sampai bercerai, dan jatuh sakit. Pada masal awal penelitian ini Maddi mengukur tingkat kepribadian tangguh karyawan IBT dan ternyata hasil menunjukkan bahwa dua pertiga karyawan yang bertahan memiliki tingkat kepribadian tangguh yang tinggi dan menunjukkan daya tahan yang baik pula, di samping itu karyawan yang bertahan juga menunjukkan emosi-emosi positif yang dapat memfasilitasi karyawan dalam menampilkan perilaku kerja inovasi. Penelitian oleh Maddi (1975-1981) menunjukkan bahwa kepribadian tangguh memiliki keterkaitan yang bersifat positif terhadap perilaku kerja inovasi. Hal ini sejalan dengan hasil penelitian ini bahwa kepeibadian tangguh berpengaruh secara signifikan terhadap perilaku kerja inovatif.

Penelitian lain yang juga sejalan dengan penelitian ini adalah penelitian yang dilakukan oleh Bartone (2008) pada pasukan khusus militer Amerika Serikat. Pasukan khusus ini memiliki tugas yang sedikit berbeda dengan pasukan militer pada umunya yaitu merupakan kelompok kecil, independen yang artinya kurang mendapatkan bantuan, dan diterjunkan pada kondisi-kondisi yang tidak pasti. Karakteristik pasukan khusus ini membutuhkan solusi secara spontan yang dapat memecahkan permasalahan. Menurut peneliti, kemampuan pasukan militer dalam memunculkan ide spontan yang dapat mengatasi permasalahan memiliki persamaan dengan perilaku kerja inovatif. Solusi yang sudah berhasil dalam mengatasi permasalahan, jika dianalisis lebih lanjut prosesnya sama dengan perilaku kerja 
inovatif, yaitu menciptakan ide untuk mengatasi permasalahan, mengajak rekanrekannya untuk turut membantu merealisasikan ide, dan melaksanakan ide sebagai solusi untuk memecahkan permasalahan.

Penelitian Bartone dkk (2008) yang menemukan bahwa kepribadian tangguh berpengaruh signifikan meskipun bersifat lemah pada kesuksesan pasukan militer khusus tersebut, yang berarti bahwa kepribadian tangguh memliki pengaruh yang signifikan terhadap inovasi para tentara militer pasukan khusus Amerika Serikat tersebut. Hasil dari penelitian ini sejalan dengan penelitian ini yaitu kepribadian tangguh memiliki berpengaruh secara signifikan terhadap perilaku kerja inovatif. Perbedaan nilai ini, menurut peneliti mungkin dikarenakan responden penelitian yang berbeda, responden penelitian Bartone dkk (2008) merupakan pasukan militer yang meski diharapkan dapat menemukan solusi untuk memecahkan masalah namun sebagai anggota militer tetap memiliki peraturanperaturan yang terikat untuk meminimalisir kegagalan dalam tugas, sedangkan pada penelitian ini partispannya adalah karyawan sebuah perusahaan yang peraturanperaturannya bersifat tidak sekaku peraturan dalam militer.

Di samping dua penelitian yang telah disebutkan sebelumnya, terdapat penelitian lain yang juga terbukti sejalan dan melihat hubungan antara kepribadian tangguh dan perilaku kerja inovatif, yaitu penelitian yang dilakukan oleh Roberg (2007). Penelitian ini dilakukan pada sampel karyawan yang menemukan bahwa kepribadian tangguh memiliki korelasi positif secara signifikan dengan inovasi individu. Penelitian oleh Roberg (2007) melibatkan responden sebanyak 266 orang yang terdiri dari laki-laki dan perempuan yang merupakan mahasiswa jenjang sarjana, master, dan doktor, dengan tingkat pendidikan terakhir paling rendah adalah SMA. Penelitian dilakukan dengan menggunakan kertas dan pensil. Responden berasal jurusan psikologi dan bisnis di San Jose University dan University of Phoenix yang sudah memiliki pekerjaan. Bidang pekerjaan dan jabatan dari responden dalam penelitian beragam. Bidang pekerjaan responden meliputi bidang informasi, perdagangan, pendidikan dan kesehatan, perhotelan dan pariwisata, manufaktur, pemerintaham, pelayanan bisnis, dan lainnya dengan jabatan sebagai seorang ahli, administrasi, penyedia jasa, eksekutif, penjual dan yang lainnya. Ukuran organisasi tempat responden bekerja juga beragam, ada yang di bawah 20, di atas 20 hingga 100, di atas 100 hingga 500, di atas 500 hingga 2.500 , di atas 2.500 hingga 10.000 dan di atas 10.000 . Alat ukur yang digunakan untuk mengukur skor kepribadian tangguh adalah Personal Views Survey III-R oleh Maddi dkk (2006) dan alat ukur kepribadian tangguh yang digunakan adalah skala perilaku kerja inovatif oleh Janssen (2000). Nilai korelasi antara kepribadian tangguh dengan perilaku kerja inovatif yang diperoleh pada penelitian Roberg (2007) adalah sebesar 0,84 .

Terdapat persamaan dan perbedaan dari penelitian yang dilakukan oleh Roberg (2007) dengan peneliti. Persamaan tersebut antara lain jenis kelamin responden, tingkat pendidikan responden, beragamnya jabatan responden dan alat ukur perilaku kerja inovatif yang digunakan. Perbedaan di antara kedua penelitian ini adalah jumlah responden, bidang pekerjaan yang beragam, ukuran organisasi responden, alat ukur kepribadian tangguh dan pada penelitian Roberg (2007) melihat korelasi sedangkan dalam penelitian ini melihat pengaruh. Jumlah responden penelitian Roberg sebanyak 266 orang dengan sebelas orang tidak disertakan dalam perhitungan sehingga total responden sebanyak 255, sedangkan pada penelitian ini jumlah responden adalah sebanyak 135 orang. Bidang pekerjaan pada penelitian ini hanya terbatas pada bidang manufaktur kapal, sedangkan pada penelitian Roberg (2007) bidang pekerjaan lebih beragam dan 
mayoritas responden bekerja pada bidang perdagangan. Ukuran organisasi pada penelitian ini berkisar pada jumlah ribuan, tepatnya sebanyak 1.300 karyawan, sedangkan pada penelitian oleh Roberg (2007), ukuran organisasi sangat beragam dan mayoritas responden berasal dari ukurang organisasi di bawah 20 orang. Terakhir yaitu, skala kepribadian tangguh yang digunakan oleh Roberg (2007) adalah Personal Views Survey III-R oleh Maddi dkk (2006) yang merupakan generasi kedua dari perkembangan alat ukur kepribadian tangguh, sedangkan pada penelitian ini, alat ukur kepribadian tangguh yang digunakan merupakan milik Bartone (2007) yang merupakan generasi ketiga dari perkembangan alat ukur kepribadian tangguh yaitu Dispositional Resilience Scale-15.

Tujuan penelitian yang berbeda antara penelitian oleh Roberg (2007) yang melihat hubungan dan penelitian ini yang melihat pengaruh, merupakan dua hal yang tidak bisa diperbandingkan secara langsung. Namun, berdasarkan komponen-komponen pada kedua penelitian, dapat memberikan informasi alasan dari hasil kedua penelitian. Pertama adalah bidang organisasi pada kedua penelitian ini. Bidang organisasi di dalamnya mencakup tuntutan kerja dan iklim organisasi. Pada penelitian yang dilakukan oleh Roberg (2007), mayoritas respondennya berasal dari bidang retail yang berarti skor responden di bidang perdagangan memberikan sumbangsih besar terhadap hasil penelitian. Pada artikel berjudul Characteristics of the Retail Industry yang dimuat dalam situs ukessays.com meletakkan adaptasi terhadap perubahan atau inovasi pada poin pertama kunci bagi industri retail untuk dapat bertahan (NN, 2017), sedangkan dalam penelitian ini, bidang pekerjaan responden merupakan manufaktur kapal, terlebih hanya dua dari empat divisi yang memang berkonsentrasi pada inovasi yaitu divisi desain yang bertugas untuk merancang kapal, mulai dari bentuk, ukuran, mesin, bahan yang membutuhkan inovasi-inovasi untuk dapat menghasilkan kapal dengan kualitas terbaik dan divisi rekayasa umum memiliki tugas untuk menghasilkan komponen-komponen yang dapat mendukung aktivitas kapal agar dapat berperforma maksimal yang berarti divisi ini membutuhkan inovasi-inovasi agar dapat menghasilkan produk dengan spesifikasi yang selalu lebih baik dari sebelumnya. Dua divisi lainnya yaitu kapal niaga dan kapal perang, secara umum bertugas untuk mengonstruksi kapal yang sudah dirancang oleh divisi desain sebelumnya dengan mengikutsertakan hasil-hasil penemuan dari divisi rekayasa umum saat mengkontruksi kapal niaga dan kapal perang. Perbedaan latar belakang bidang kerja responden, dengan tuntutan kerja dan iklim kerja yang berbeda pula, menurut peneliti hal inilah menyebabkan nilai korelasi pada penelitian Roberg (2007) tinggi yang berarti korelasi kepribadian tangguh dengan perilaku kerja inovatif sangat kuat dan pada penelitian ini meski kepribadian tangguh secara signifikan berpengaruh terhadap perilaku kerja inovatif namun pengaruhnya tidak terlalu besar, sehingga mayoritas karyawan juga hanya menampilkan perilaku kerja inovatif pada tingkat sedang.

Terakhir, ditinjau dari segi ukuran organisasi, ukuran organisasi pada penelitian Roberg (2007) mayoritas berasal dari perusahaan dengan jumlah karyawan di bawah 20. Jumlah karyawan yang terbilang masih sedikit tersebut dapat menjadi pertanda bahwa perusahaan tersebut baru saja terbentuk dan membutuhkan pengembangan-pengembangan. Perusahaan tempat peneliti mengambil data merupakan perusahaan BUMN yang sering mendapat pesanan-pesanan kapal dari pemerintah, dapat dikatakan persaingan PT $\mathrm{X}$ dengan perusahaan yang bergerak di industri yang sama tidak terlalu besar karena perusahaan $\mathrm{X}$ memiliki pelanggan tetap. Berdasarkan hal ini, peneliti menganalisis bahwa perbedaan dari segi kebutuhan untuk menampilkan perilaku kerja inovatif merupakan salah satu faktor yang 
menyebabkan nilai korelasi pada penelitian Roberg (2007) tinggi dan pada penelitian ini memiliki perilaku kerja inovatif yang ditampilkan karyawan PT X berada pada tingkat sedang.

Berdasarkan hasil analisis penelitian yang menemukan bahwa bahwa 16,6\% perilaku kerja inovatif dipengaruhi oleh kepribadian tangguh dan sisanya sebesar $83,4 \%$ dipengaruhi oleh faktor lain selain kepribadian tangguh. Di bawah ini, akan dibahas mengenai rincian dan analisis peneliti atas data yang peneliti dapatkan. Berdasarkan hasil analisis mengenai gambaran umum kepribadian tangguh dan perilaku kerja inovatif kaywan PT X mayoritas karyawan memiliki tingkat kepribadian tangguh yang sedang dan mayoritas menampilkan perilaku kerja inovatif yang sedang pula. Tidak ada karyawan yang memiliki tingkat kepribadian tangguh yang rendah namun, terdapat $13,3 \%$ atau sebanyak 18 responden menampilkan perilaku kerja inovatif yang rendah. Oleh karena itu, peneliti meninjau faktor demografis dari 18 responden yang menampilkan perilaku kerja inovatif yang rendah tersebut.

Berdasarkan peninjuan terhadap faktor demografis, banyak dari ke-18 responden tersebut yang berjenis kelamin perempuan, adapun responden laki-lakinya banyak yang memiliki masa kerja di bawah sepuluh tahun. Kedua hal ini yang menurut peneliti dapat memberikan tambahan penjelasan mengapa terdapat karyawan yang menampilkan perilaku kerja inovatif rendah meskipun tidak ada karyawan yang memiliki tingkat kepribadian rendah. Menurut penelitian oleh Costa dkk (2001) perempuan lebih submissive atau mengikuti peraturan yang sudah ada dibandingkan laki-laki membuat perempuan kurang menampilkan perilaku kerja inovatif. Di samping itu, Tierney dan Farmer (2004) berpendapat bahwa lama kerja dapat menggambarkan pengetahuan yang didapatkan karyawan melalui pelatihan dan pengalaman yang didapatkan saat bekerja. Hal ini dapat menjelaskan mengapa terdapat karyawan yang menampilkan perilaku kerja inovatif rendah. Masa kerja yang belum terlalu lama, menyebabkan karyawan belum memiliki pengetahuan yang cukup untuk dapat bereaksi dengan tepat terhadap permasalahan atau dalam hal ini menampilkan perilaku kerja inovatif

\section{SIMPULAN}

Penelitian ini bertujuan untuk mengetahui apakah kepribadian tangguh secara signifikan memengaruhi perilaku kerja inovatif. Berdasarkan hasil analisis yang dilakukan untuk menjawab pertanyaan tersebut menunjukkan bahwa, kepribadian tangguh secara signifikan berhubungan dengan perilaku kerja inovatif dan memengaruhi munculnya perilaku kerja inovatif pada karyawan PT X.

\section{SARAN}

Berdasarkan hasil analisis dan evaluasi terhadap penelitian ini, peneliti menyarankan agar pada penelitian selanjutnya untuk mempertimbangkan pemilihan divisi yang berkonsentrasi pada inovasi, agar mendapatkan hasil penelitian yang lebih tajam mengenai perilaku kerja inovatif. Kedua, peninjauan kembali terhadap alat ukur DRS-15 akan membuat alat ukur menjadi lebih baik, karena ditemukan bahwa pernyataan dalam alat ukur DRS-15 ini mengarahkan responden untuk cenderung memilih jawaban tertentu atau dengan kata lain memiliki tingkat social desirability yang tinggi.

Pada penelitian ini, terdapat beberapa kuesioner yang tidak terisi penuh dan beberapa data demografis kosong. Oleh karena itu, pada penelitian selanjutnya perlu diperhatikan persiapan prosedur izin pengambilan data pada perusahaan terkait agar proses pengambilan data lebih matang dan dapat menimalisir kesalahan yang terjadi. Di samping itu, dapat pula dilakukan pendampingan selama proses pengisian guna meminimalisir adanya kesalahan pengisian atau adanya kekosongan pada butir pernyataan ataupun data demografis. 
Berdasarkan hasil penelitian yang menunjukkan adanya pengaruh kepribadian tangguh terhadap perilaku kerja inovatif dapat dijadikan pertimbangan bagi perusahaan untuk mengadakan pelatihan yang dapat meningkatkan kepribadian tangguh, sehingga dapat memperbesar kemungkinan bagi para karyawan untuk menampilkan perilaku kerja inovatif yang bermanfaat bagi perusahaan, seperti dengan pelatihan coping secara kognitif, emosi, dan reaksi saat menemui permasalahan, cara berinteraksi sosial, dan cara menjaga diri sendiri. Perusahaan juga dapat mempertimbangkan mapping mengenai kepribadian tangguh karyawan atau dengan menempatkan karyawan yang memiliki kepribadian tangguh yang tinggi pada pekerjaan-pekerjaan yang membutuhkan inovasi. Terakhir, dikarenakan hasil yang menunjukkan bahwa perilaku kerja inovatif tinggi pada karyawan dengan masa kerja di atas sepuluh tahun maka, perusahaan dapat mempertimbangkan cara-cara yang dapat membuat karyawan betah atau bertahan lama di perusahaan seperti dengan pemberian apresiasi terhadap kinerja karyawan atau iklim organisasi yang dapat ditingkatkan.

\section{DAFTAR PUSTAKA}

Amabile, T. M., Barsade, S. G., Mueller, J. S., \& Staw, B. M. (2005). Affect and creativity at work. Administrative Science Quarterly, 50(3), 367-403.

Bartone, P. T., Ursano, R. J., Wright, K. M., \& Ingraham, L. H. (1989). The impact of a military air disaster on the health of assistance workers: A prospective study. The Journal of Nervous and Mental Disease, 177(6), 317-328.

Bartone, P. T., Roland, R. R., Picano, J. J., \& Williams, T. J. (2008). Psychological hardiness predicts success in US Army Special Forces candidates. International Journal of Selection and Assessment, 16(1), 7881.
De Jong, J. P., \& Den Hartog, D. N. (2007). How leaders influence employees' innovative behaviour. European Journal of Innovation Management, 10(1), 41-64.

Etikariena, A., \& Muluk, H. (2014). Hubungan antara Memori Organisasi dan Perilaku Inovatif Karyawan. Makara Hubs-Asia, 8(3), 77-88. doi 10.7454/mssh.v18i2.3463.

Fox, M. L., Dwyer, D. J., \& Ganster, D. C. (1993). Effects of stressful job demands and control on physiological and attitudinal outcomes in a hospital setting. Academy of Management Journal, 36(2), 289-318.

Hammond, M. M., Neff, N. L., Farr, J. L., Schwall, A. R., \& Zhao, X. (2011). Predictors of individual-level innovation at work: A meta-analysis. Psychology of Aesthetics, Creativity, and the Arts, 5(1), 90-105.

Hana, U. (2013). Competitive Advantage Achievement through Innovation and Knowledge. Journal of Competitiveness, 5(1). 88-96. doi 10.7441/joc.2013.01.06.

Janssen, O. (2003). Innovative behaviour and job involvement at the price of conflict and less satisfactory relations with co-workers. Journal of Occupational and Organizational Psychology, 76(3), 347-364.

Janssen, O., Van de Vliert, E., \& West, M. (2004). The bright and dark sides of individual and group innovation: A special issue introduction. Journal of Organizational Behavior, 25(2), 129145.

Kanter, R. (1988). When a thousand flowers bloom: Structural, collective, and social conditions for innovation in organizations. In B. M. Staw \& L. L. Cummings (Eds), Research in organizational behavior (pp.169211). Greenwich, CT: JAI Press.

Kobasa, S. C. (1982). The hardy personality: Toward a social psychology of stress and 
health. Social Psychology of Health and Illness, 4, 3-32.

Li, N., Barrick, M. R., Zimmerman, R. D., \& Chiaburu, D. S. (2014). Retaining the productive employee: The role of personality. Academy of Management Annals, 8(1), 347-395.

Maddi, S. R. (2006). Hardiness: The courage to grow from stresses. The Journal of Positive Psychology, 1(3), 160-168.

Maddi, S.R. (2013). Personal hardiness as the basis for resilience. In S.R. Maddi, Hardiness: Turning stressful circumstances into resilient growth (pp. 7-17). Netherlands: Springer.

Novena, M.M.N (2013). Program intervensi untuk meningkatkan work engagement pada PT XYZ berdasarkan variabel procedural justice, psychological hardiness dan commitment to change (Tesis). Universitas Indonesia, Depok, Indonesia.

Roberg, L. C. (2007). Organizational empowerment and hardiness as predictors of innovativeness (Tesis). San Jose State University, San Jose, Amerika Serikat.

Roberts, B. W., Kuncel, N. R., Shiner, R., Caspi, A., \& Goldberg, L. R. (2007). The power of personality: The comparative validity of personality traits, socioeconomic status, and cognitive ability for predicting important life outcomes. Perspectives on Psychological Science, 2(4), 313345.

Scott, S. G., \& Bruce, R. A. (1994). Determinants of innovative behavior: A path model of individual innovation in the workplace. Academy of Management Journal, 37(3), 580-607.

Tierney, P., \& Farmer, S. M. (2004). The pygmalion process and employee creativity. Journal of Management, 30(3), 413-432.

Vinarski-Peretz, H., \& Carmeli, A. (2011).

Linking Care Felt to Engagement in
Innovative Behaviors in the Workplace: The Mediating Role of Psychological Conditions. Psychology of Aesthetics, Creativity, and the Arts, 5(1), 43-52.

West, M.A., and Farr, J.L. (1990). Innovation at work. In M.A. West and J.L. Farr (Eds), Innovation and creativity at work: Psychological and organizational strategies (pp. 3-13). Chichester, England: Wiley.

Yosephine, C. (2013). Hubungan antara perilaku kerja inovatif dan stres kerja pada karyawan PT X dan PT Y. Universitas Indonesia, Depok, Indonesia. 